\title{
Sports Medicine - Open
}

Roger Olney and Steve McMillan ${ }^{*}$

\section{Dear Sports Medicine and Exercise Researchers,}

It is with great pleasure that Springer announces the launch of Sports Medicine - Open, a new peer-reviewed, online-only, open-access journal designed to provide an avenue for publication of original research in the field of sports and exercise medicine.

Sports Medicine - Open is a sister publication of Sports Medicine, which has been published since 1984 by Adis and is now part of the Springer journal portfolio. The original Sports Medicine journal has been a leading publication in sports and exercise medicine for 30 years and has consistently been one of the most highly ranked vehicles for publication of review articles in the field. This focus on reviews has left little scope for the inclusion of original research, although Sports Medicine regularly receives submissions of original research articles. The launch of a sister journal to Sports Medicine, publishing original research, aims to provide the first top-tier openaccess avenue for these papers. Given the well-regarded Sports Medicine brand and the community of top-tier researchers that support the journal, we believe that Sports Medicine - Open will fill a gap for our target audience of sports medicine practitioners, physiotherapists, exercise scientists/physiologists, team doctors, and trainers.

Sports Medicine - Open will have similar aims and scope to those of the original Sports Medicine journal but with a different, complementary focus. Specifically, Sports Medicine - Open aims to publish original medical and scientific research in the following areas:

- Sporting performance enhancement

- Medical syndromes associated with sport and exercise

- Injury prevention and treatment

- Exercise for rehabilitation and health

- The application of physiological and biomechanical principles to specific sports
Sports Medicine - Open will also consider publication of a smaller number of high-interest, definitive reviews. To ensure consistency and continuity of the editorial services associated with the original Sports Medicine journal, Sports Medicine - Open will be managed by an expanded team based on the editorial staff responsible for the original journal. Thus, authors will enjoy the benefits of publishing in a journal following the strong publishing practices of Sports Medicine, with the same editorial and publishing expertise and experience associated with that journal.

Springer publishes more than 2,200 journals, including over 500 in its Medicine Journal Collection. The successful integration of the Adis portfolio of journals into the Springer production systems and custombuilt platforms (SpringerLink, Springer for R\&D, and Springer for Hospitals \& Health) means that authors now have:

- Easy article submission, peer review, and tracking processes

- Shorter time to publication

- Unparalleled article visibility, worldwide reach and discoverability

- Convenient, global, online access of readers to their work

These benefits of the Springer organization will flow into the new Sports Medicine - Open journal from its inception.

Therefore, our final message is a simple one: if you have an original research article in the sports and exercise field that you believe would be a candidate for publication in Sports Medicine - Open, please submit your manuscript to us for an assessment. With the support of both the community of researchers who publish review articles in the original Sports Medicine journal, and the large number of other readers and followers of the journal, we believe that we can quickly establish a journal that provides a high-quality, open-access option for

\footnotetext{
* Correspondence: steve.mcmillan@springer.com
}

Auckland, New Zealand

\section{Springer}

(C) 2015 Olney and McMillan; licensee Springer. This is an Open Access article distributed under the terms of the Creative Commons Attribution License (http://creativecommons.org/licenses/by/4.0), which permits unrestricted use, distribution, and reproduction in any medium, provided the original work is properly credited. 
researchers in the field. We ask you, particularly if you are a 'friend' of the original Sports Medicine journal, to keep Sports Medicine - Open in mind when considering where to submit your original research.

Yours sincerely

Roger Olney and Steve McMillan, Editors editorial@sportsmedicine-open.com

Published online: 20 January 2015

Submit your manuscript to a SpringerOpen ${ }^{\circ}$ journal and benefit from:

- Convenient online submission

- Rigorous peer review

- Immediate publication on acceptance

- Open access: articles freely available online

- High visibility within the field

- Retaining the copyright to your article

Submit your next manuscript at $\boldsymbol{\nabla}$ springeropen.com 